\title{
足関節外側側副靯帯損傷に対する装具の試作
}

\author{
長崎大学整形外科 \\ 松 坂 誠 應 - 乗 松 敏 晴 \\ 寺本司 \\ 長崎大学理学療法部 \\ 藤 田 雅 章 - 大 城 昌 平 \\ 愛野記念病院整形外科 \\ 平 野 英 二
}

\section{Evaluation of Effects of Orthosis for Injury of the Lateral Ligaments of the Ankle}

by

\section{Nobuo Matsusaka, Masaaki Fujita, Toshiharu Norimatsu, Tsukasa Teramoto and Shohei Ogi \\ Department of Orthopaedic Surgery, Nagasaki University School of Medicine}

\section{Eiji Hirano}

Aino Memorial Hospital Orthopaedic Surgery

\begin{abstract}
A special orthosis as an alternative to ankle taping was manufactured for the patients with injury of the lateral ligaments of the ankle. The device was applied over a cotton sock and tightened over the malleoli, the foot resting on a plastic sole with lateral strap. It was designed to hold the ankle in a neutral position avoiding inversion, dorsiflexion and plantar flexion of the ankle necessary for play.

The effects of the orthosis were evaluated from the viewpoint of the mechanical and functional instability. X-ray stress examination was performed as assessment of mechanical instability. Talar tilt angle and anterior displacement improved significantly using the orthosis from 11.4 degrees to 2 . 5 degrees, and from $7 \mathrm{~mm}$ to $3.6 \mathrm{~mm}$ respectively. Stabilometry was used for quantitative assessment of functional instability. Stabilometric value improved significantly from $172 \mathrm{~mm}^{2}$ to $130 \mathrm{~mm}^{2}$ using the orthosis.
\end{abstract}

These results indicated that this orthosis is very useful for injury of the lateral ligaments of the ankle.

\section{は じめに}

足関節外側側副勒帯損傷に対して種々の治療法が行 われそれぞれに比較的良好な成績が報告されている。 われわれは 1982 年より Gould 法を行い, 良好な成績 を得ている. Gould 法4) の後療法に従い, 術後 4 週のギ プス固定のあと 2 週間のテーピングによる固定を行っ
てきた。しかし，テーピングにはテクニック修得の問 題や, その効果持続時間の問題が指摘されている ${ }^{6) 111}$. 今回, われわれはテーピングに代わる装具を考案し, その有用性について足関節外側側副勒帯損傷の機械的 不安定性と機能的不安定性の観点から検討した。

装具

Tropp ら ${ }^{10)}$ の報告したものに改良を加えた. 装具は 


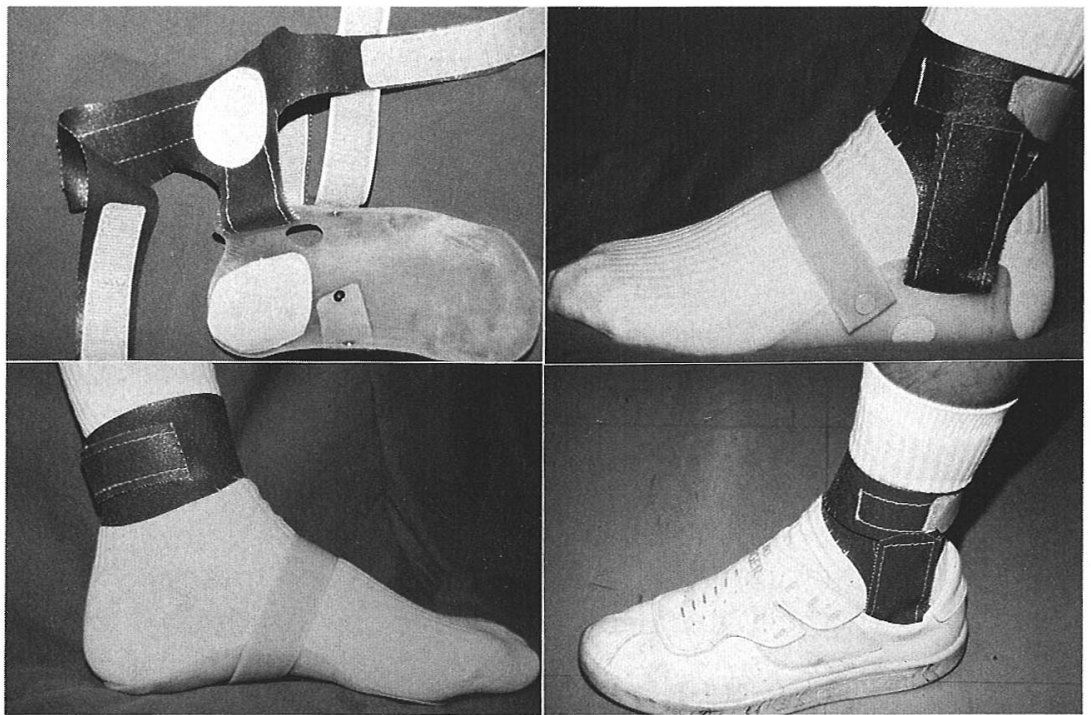

図 1 装具. 靴インサートと外側ストラップより構成される

靴インサートと外側ストラップより構成され，足関節 の背底屈は可能とし足関節の内反を防ぐ構造となって いる、靴インサートはホリプロピレンを用い, 踵部に はソルボンセイン樹脂を敷き, 中足部は足内側アーチ を支えるようにモデリングし，前足部は MTP 関節の 背届が円滑に行えるように厚さを $0.3 \mathrm{~mm}$ 程とした。 ストラップは，両果上部を巻き固定する果部ストラッ プと靴インサート外側で折り返し足関節内反を防ぐス トラップからなっている. ストラップの材質はテトロ ン帆布を用い伸縮を防いだ。また，装具を着用してス ポーツができるようにしている(図1)。

対 象

受傷後 3 力月以上経過した陳旧性足関節外側側副鞄 帯損傷 15 例を対象とした. 年令は $14 \sim 42$ 才で平均 25 才で，男 6 例女 9 例であった。 対象 15 例のうち, 繰り 返す足関節捻挫や足関節の giving way を訴える。いわ ゆる機能的不安定性を有するものは 12 例に認められた。

方法

機械的不安定性の定量的評価には Tropp らが報告し ている患肢片脚起立時の重心動摇検查法に従った9).ア ニマ社製ダラビコーダ G-5500を用い患肢片脚起立を 60 秒間保持させた。上肢は，その動きの影響をなくす
ために前胸部で腕を組ませた。得られた重心動摇のデ ータよりマイクロコンピュータ (PC-9801)にて重心位 置のヒストグラムを左右, 前後方向について求め, そ の集中，ばらつきの度合を検討するために各々の標準 偏差を算出した。ついで，重心動摇図に拈いて左右方 向 $(\mathrm{X})$ と前後方向 $(\mathrm{Y})$ の $-\mathrm{SD} \sim+\mathrm{SD}$ の範囲で囲 まれた部分の面積を重心動摇集中面積 (SDarea) とし て求めた(図 2 )。この場合も装具装着時と非装着時に ついて検討した。

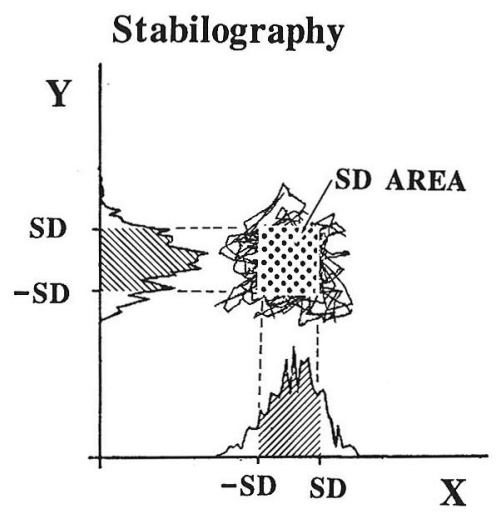

図 2 重心動摇検査法. SD：標準偏差 SD AREA：重 心動摇集中面積 
結

果

機械的不安定性の評価において, 距骨傾斜角は装具 非装着 $11.4^{\circ} \pm 4.9^{\circ}$ であったが, 装具装着によって $2.5^{\circ} \pm$ $2.3^{\circ}$ と正常範囲に有意に改善した。距骨前方移動度は, 装具非装着時 $7.0 \mathrm{~mm} \pm 1.6 \mathrm{~mm}$ であったが, 装具装着 によって $3.6 \mathrm{~mm} \pm 0.6 \mathrm{~mm}$ と有意に改善した。装具装 着時の值は正常値 $3 \mathrm{~mm}$ と有意差はなかった（図 3 ）.

機能的不安定性の評価において, 重心動摇集中面積 は装具非装着時には平均 $172 \mathrm{~mm}^{2} \pm 48 \mathrm{~mm}^{2}$ であった が, 装具装着によって平均 $131 \mathrm{~mm}^{2} \pm 32 \mathrm{~mm}^{2}$ と有意に

\section{Evaluation of Mechanical Instability $N=15$} Varus. Stress Test Ant. Drawer Test
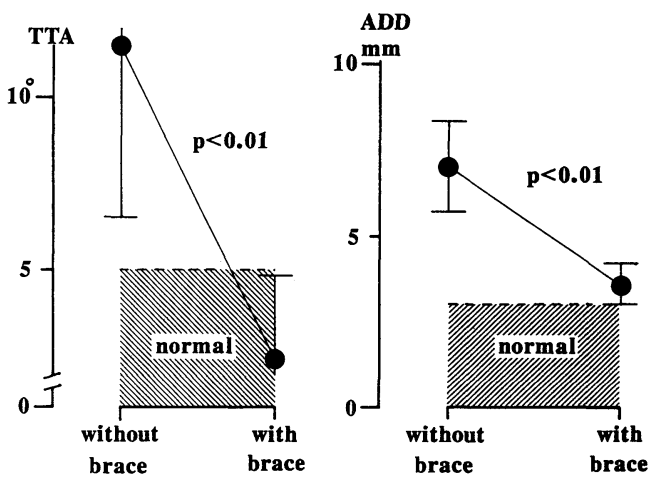

図 3 機械的不安定性の検討

改善した.この值も正常值 $110 \mathrm{~mm}^{2}$ と有意差はなかっ た. 左右方向の重心位置ヒストグラムの標準偏差は装 具非装着時平均 $6.4 \mathrm{~mm} \pm 0.6 \mathrm{~mm}$ であったが, 装具装 着によって平均 $5.5 \mathrm{~mm} \pm 0.4 \mathrm{~mm}$ と有意に小さくなり 正常範囲となった. しかし，前後方向の重心位置ヒス トグラムの標準偏差は有意の改善は認められなかった (困 4 ).

\section{考察}

X線ストレス撮影にて距骨傾斜角および距骨前方移 動度ともに，本装具によって有意に改善したが，距骨 前方移動度の改善は距骨傾斜角ほど著明でなかった。 これは装具装着時に足関節の背底屈を可能としたため 距骨の前方制動が内反制動にくらべ，それ程強くなか ったからと考える.しかし，装具によって距骨傾斜角， 距骨前方移動度ともにほぼ正常となっていることから, 本装具は機械的不安定性に対して有用と思われる。

機能的不安定性は足関節捻挫の後遺症として多くの 報告があるが(12)7(8)10), 定量的な試みはなされなかった。 Tropp ら ${ }^{9)}$ は姿勢制御の観点から重心動摇検查法を用 いて機能的不安定性の定量化を行い，機能的不安定性 を有する症例では有意に高值をとることを報告した。 われわれも同様な方法で評価したが，機能的不安定性 を有する場合, 平均 $172 \mathrm{~mm}^{2}$ と有意に高值を示し Tropp らの結果と一致した。装具装着によって有意に

\section{Evaluation of Functional Instability $\quad \mathrm{N}=12$}
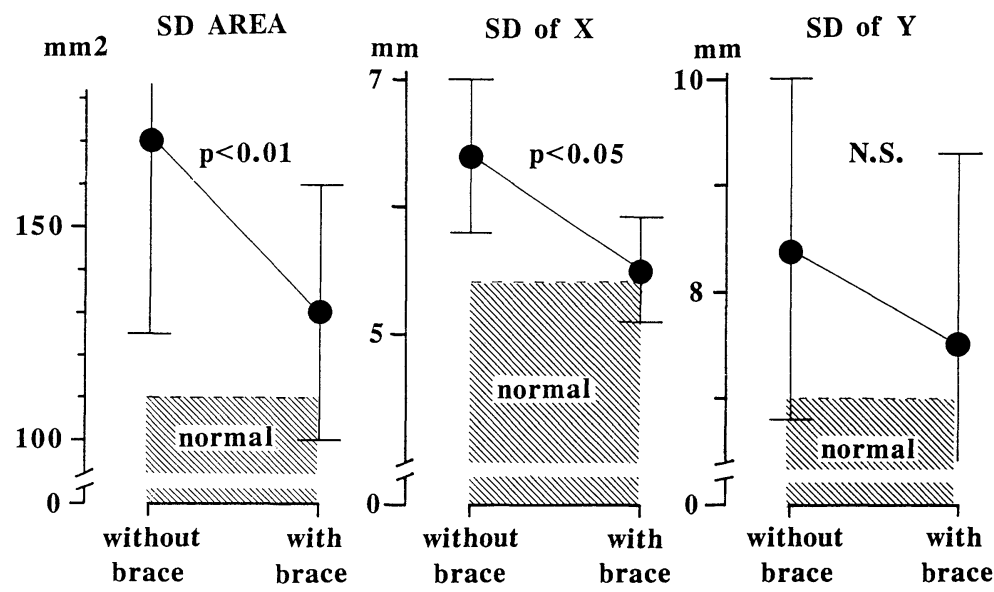

図 4 機能的不安定性の検討 
改善し，ほほ正常範囲となったがこれは左右方向の重 心同様のばらつきが小さくなったためと考えられ，本 装具は機能的不安定性に対しても有用と思われる。

機能的不安定性の原因については論議のあるところ である. Bosien ${ }^{1)}$, Staples ${ }^{8)}$, Tropp $^{10)}$ は 2 次的な腓骨 筋の筋力低下を挙げ, Prins ${ }^{7)}$ は, 機械的不安定性との 関係を報告し,長谷川 ${ }^{5)}$ はとくに距骨傾斜角との相関を 述べている. 本装具による機能的不安定性の改善は, 機械的不安定性, とくに距骨傾斜角の改善によるもの かもしれない. 片脚起立時に足関節の内反方向への動 きに対し腓骨筋は制動的に働く.しかし, 機能的不安 定性を有する場合, Staples ${ }^{8)}$, Tropp ${ }^{10)}$, Freeman ${ }^{3)}$ の 考えによれば，腓骨筋の筋力低下， proprioceptive reflex 障害によって腓骨筋の対応が障害されてくる。本 装具によって足関節は内外反中間位からやや外反位に 保持されており, 先に述べた腓骨筋の機能不全を本装 具が補っているとも考えられる。

Tropp らは機械的不安定性の有無にかかわらず機能 的不安定性は存在すると報告している。これは機械的 不安定性を手術等で改善しても術後に繰り返す足関節 捻挫や足関節の giving way などを訴える可能性を意味 する。したがって，われわれは本䩲帯損傷患者に対し 腓骨筋の筋力強化, coordination 障害の改善のため ankle disc 上の訓練を指導し, スポーツ選手には運動 時に本装具の着用をすすめている.

$$
\text { ま と め }
$$

1. 足関節外側側副鞀帯損傷に対する装具の有用性 について, 機械的不安定性と機能的不安定性の観点か
ら検討した。

2. 本装具によって機械的不安定性, 機能的不安定 性は改善され本装具は足関節外側側副勒帯損傷に対し 有用と思われる。

\section{参 考 文 献}

1) Bosien, W. R. et al. : Residual disability following acute ankle sprains. J Bone Joint Surg 37-A : 12371243, 1955.

2) Freeman, M. A. R. : Instability of the foot after injuries to the lateral ligament of the ankle. J Bone Joint Surg 47-B : 669-677, 1965.

3) Freeman, M. A. R. : The etiology and prevention of functional instability of the foot. J Bone Joint Surg 47-B : 678-685, 1965.

4) Gould, N. et al.: Early and late repair of lateral ligament of the ankle. Foot Ankle 1: 84-89, 1980.

5）長谷川惊：陳旧性足関節勒带損傷に対する手術的療 法とその成績について。臨床スポーツ医学, $4: 409-416$, 1987.

6）鹿倉二郎：スポーツ選手のためのテーピング. 整形・ 災害外科, $25: 1657-1644,1982$.

7) Prins, J. G. : Diagnosis and treatment of injury to the lateral ligament of the ankle. Acta Chir Scand Suppl. 486, 1978.

8) Staples, O. S. : Result study of lateral ligaments of the ankle. Clin Orthop 85: 50-58, 1972.

9) Tropp, H. et al. : Stabilometry in functional instability of the ankle and its value in predicting injury. Med Sci Sports Exerc. 16: 64-66, 1984.

10) Tropp, H. : Functional instability of the ankle. Linköping Univ. Medical Dissertation 202, 1985.

11）梅ケ枝健一：足関節捻挫とテーピング. 整形・災害外 科, $27: 663-667,1984$. 